\title{
HISTORIS, DAYA TARIK WISATA DAN ELECTRONIC WORD OF MOUTH (E-WOM) TERHADAP KEPUTUSAN BERKUNJUNG DI DE TJOLOMADOE
}

\author{
Nova Dwi Susanti \\ novasusanti95.nd@gmail.com \\ Ida Aryati \\ Ratna Damayanti \\ Fakultas Ekonomi Manajemen Universitas Islam Batik Surakarta
}

diterima: 10/4/2018; direvisi: 22/2/2019; diterbitkan: 31/8/2019

\begin{abstract}
The purpose of this research is to analyze the effect of either simultaneously or partial historical, tourist attraction and electronic word of mouth to decision visit in De Tjolomadoe Karanganyar, Central Java. The research uses descriptive quantitative. The population is visitors at De Tjolomadoe Karanganyar, Central Java. The sample is 100 respondents. Sampling technique uses accidental sampling. The technique used to analyze the data is multiple linier regression. The results of F-test shows that historical, tourist attraction and electronic word of mouth (e-WOM) have simultaneous and significant influence to decision visit. The results of t-test showed that historical, tourist attraction, electronic word of mouth have positive and significant influence to decision visit in De Tjolomadoe Karanganyar Central Java.
\end{abstract}

Keywords: historical; tourist attraction; electronic word of mouth; decision visit

\begin{abstract}
Abstrak
Tujuan dari penelitian ini adalah untuk menganalisis pengaruh secara simultan atau parsial historis, daya tarik wisata dan electronic word of mouth (e-WOM) terhadap keputusan berkunjung di De Tjolomadoe Karanganyar, Jawa Tengah. Jenis penelitian kuantitatif deskriptif. Populasinya pengunjung di De Tjolomadoe Karanganyar, Jawa Tengah. Sampelnya 100 pengunjung. Teknik pengambilan sampel accidental sampling. Teknik analisis data regresi linier berganda. Hasil uji F membuktikan bahwa historis, daya tarik wisata, dan e-WOM secara simultan dan signifikan mempengaruhi keputusan berkunjung. Hasil uji t membuktikan bahwa historis, daya tarik wisata dan electronic word of mouth berpengaruh positif dan signifikan terhadap keputusan berkunjung secara parsial di De Tjolomadoe.
\end{abstract}

Kata Kunci: historis; daya tarik wisata; electronic word of mouth; keputusan berkunjung 


\section{PENDAHULUAN}

Di era globalisasi, sektor pariwisata menjadi salah satu industri utama pendorong perekonomian dunia. Berbagai organisasi internasional antara lain PBB, Bank Dunia dan World Tourism Organization (WTO) mengakui bahwa pariwisata merupakan bagian yang tidak terpisahkan dari kehidupan sosial dan ekonomi manusia. Di Indonesia, pertumbuhan dan perkembangan pariwisata terbilang sangat pesat, hal tersebut terlihat pada pandangan masyarakat bahwa pariwisata bukan lagi sesuatu yang asing dan tabu, tetapi kini kebutuhan dan keinginan berwisata telah menjadi bagian dari gaya hidup masyarakat (Setiyorini, Farida, \& Kristiyana, 2018).

Setiap pengunjung memiliki sikap yang berbedabeda terhadap obyek yang sama, sehingga sebelum melakukan keputusan berkunjung sebaiknya wisatawan terlebih dahulu mencari informasi tentang obyek wisata yang akan dituju (Ramadhan, 2016).

Keputusan berkunjung merupakan kegiatan yang sangat kompleks terjadi dan melalui proses panjang, keputusan muncul dari rasa ingin tahu akan obyek wisata, tindakan yang dilakukan wisatawan mulai dari memilih tempat, proses pencarian informasi sampai pada waktu berkunjung (Smallman \& Moore, 2010).

Obyek wisata tidak terlepas dari kejadian masa lalu yang menjadi sejarah tempat tersebut. Historis atau sejarah merupakan peninggalan berbagai peristiwa yang terjadi di masa lalu dan diharapkan mampu dipahami oleh generasi penerus sebagai pelajaran hidup untuk masa depan (Fuadillah \& Soebijantoro, 2016).

Pariwisata merupakan suatu perjalanan yang memiliki tujuan memenuhi rasa ingin tahu seseorang, perjalanan tersebut merupakan wujud dari ketertarikan seseorang pada suatu obyek wisata. Daya tarik wisata merupakan potensi yang terdapat pada destinasi wisata, potensi tersebut menyajikan informasi-informasi produk pariwisata yang sangat menarik untuk dinikmati (Ramadhan, 2016).

Informasi yang didapatkan dari media internet tentu akan mempengaruhi seseorang untuk mengambil keputusan. Salah satu alat pemasaran yang efektif dalam mempengaruhi keputusan calon wisatawan merupakan komunikasi dari mulut ke mulut atau sering disebut dengan word of mouth (WOM), seiring perkembangan internet yang semakin pesat, menjadikan informasi word of mouth mengalami modernisasi menjadi electronic word of mouth (Hapsari, Lubis, \& Widiartanto, 2013). Penerapan strategi electronic word of mouth (ewom) sangat efektif untuk menyentuh hati para pengunjung (Bataineh, 2015).

De Tjolomadoe adalah Bekas Pabrik Gula (PG) Colomadu yang diubah menjadi destinasi wisata warisan budaya. De Tjolomadoe terletak di Paulan Wetan, Malangjiwan, Colomadu, Kabupaten Karanganyar, Jawa Tengah. Pabrik Gula didirikan Mangkunegaran IV pada tahun 1861 .
Pada tahun 2017, Sejumlah badan Usaha Milik Negara (BUMN), di antaranya PT PP (Persero) Tbk, PT PP Properti Tbk, PT Taman Wisata Candi Prambanan, Borobudur, dan Ratu Boko (Persero), serta PT Jasa Marga Properti membentuk Joint Venture dengan nama PT Sinergi Colomadu untuk melaksanakan konstruksi revitalisasi dengan mengikuti kaidah cagar budaya.

Pemerintah menjamin aset eks pabrik gula Colomadu yang dikelola oleh PTPN IX (Persero) dan PT PP (Persero) sebagai kawasan heritage dan wisata baru tidak akan berubah keaslian bangunan dan memperhatikan kaidah cagar budaya.

Berdasar latar belakang diatas, perumusan masalahnya yaitu apakah terdapat pengaruh secara simultan dan parsial historis, daya tarik wisata dan electronic word of mouth terhadap keputusan berkunjung di De Tjolomadoe Karanganyar Jawa Tengah. Tujuan penelitian ini yaitu mengetahui pengaruh secara simultan dan parsial historis, daya tarik wisata dan electronic word of mouth terhadap keputusan berkunjung di De Tjolomadoe Karanganyar Jawa Tengah.

Kaitannya dengan dunia pariwisata, keputusan pembelian diasumsikan sebagai keputusan berkunjung sehingga teori-teori mengenai keputusan pembelian juga digunakan dalam keputusan berkunjung (Mustikasari \& Widaningsih, 2016). Keputusan pembelian merupakan suatu keputusan (decision), dimana keputusan menjelaskan antara pilihan yang berbeda (Abdullah dan Tantri, 2012: 113).

Sejarah merupakan kejadian masa lalu yang menjadi asal mula dari masa kini (Hamid dan Madjid, 2011: 3). Hamid dan Madjid (2011: 8) menjelaskan bahwa sejarah memiliki dua aspek penting, antara lain: (a) Sejarah dalam arti subjektif sebagai suatu konstruksi atau bangunan yang disusun oleh sejarawan sebagai suatu uraian atau cerita; (b) Sejarah dalam arti objektif yang menunjuk kepada kejadian atau peristiwa itu sendiri, sebagai proses dalam aktualitasnya.

Simanjuntak dkk (2017: 24) mendefinisikan daya tarik merupakan segala sesuatu yang menyebabkan seseorang untuk mengunjungi suatu tempat. Daya tarik wisata merupakan fokus utama penggerak pariwisata di sebuah destinasi, daya tarik wisata sebagai penggerak utama yang memotivasi wisatawan untuk mengunjungi suatu tempat (Ismayanti, 2009: 147).

Hasan (2010: 29) menjelaskan Word of Mouth Marketing (WOMM) adalah sebuah percakapan yang didesain secara online maupun offline. Seiring berkembangnya teknologi, WOM dapat dilakukan melalui internet yang biasa disebut Electronic Word of Mouth (e-WOM). Komunikasi e-WOM meliputi pendapat konsumen tentang produk atau jasa yang di posting di internet (Malau, 2017: 292).

Diduga historis, daya tarik wisata dan electronic word of mouth (ewom) berpengaruh secara simultan dan signifikan terhadap keputusan berkunjung di De Tjolomadoe Karanganyar Jawa Tengah. 
Diduga historis berpengaruh secara positif dan signifikan terhadap keputusan Berkunjung di De Tjolomadoe Karanganyar Jawa Tengah. Diduga daya tarik wisata berpengaruh secara positif dan signifikan terhadap keputusan berkunjung di De Tjolomadoe Karanganyar Jawa Tengah. Diduga electronic word of mouth (ewom) berpengaruh secara positif dan signifikan terhadap keputusan berkunjung di De Tjolomadoe Karanganyar Jawa Tengah. Kerangka pemikiran ditunjukkan pada Gambar 1.

\section{METODE}

Jenis penelitian yaitu deskriptif kuantitatif. Populasinya yaitu pengunjung wisata di De Tjolomadoe, Karanganyar, Jawa Tengah dengan sampel 100 responden. Data diperoleh dari kuesioner dengan teknik pengambilan sampel accidental sampling. Teknik analisis data pada penelitian yaitu uji asumsi klasik, regresi linier berganda, uji F, uji t dan uji determinasi $\left(\mathrm{R}^{2}\right)$.

\section{HASIL}

Uji normalitas memiliki sebaran data yang normal. Hasil pengujian Kolomogorov - Smirnov - Test, nilai p-value 0,955 . Nilai signifikansi yaitu sebesar $0,955>$ 0,05 (Tabel 1). Hasil uji multikolinearitas menunjukkan bahwa model regresi pada penelitian ini tidak terjadi multikolinieritas. Diperoleh dari tolerance value $>$ 0,10, pada VIF kurang dari 10 (Tabel 2). Hasil uji Glejser menunjukkan bahwa model regresi tidak terjadi heteroskedastisitas. Dilihat dari nilai probabilitas signifikansi pada variabel independen lebih dari 0,05 (Tabel 3).

Uji regresi linear berganda digunakan untuk mengetahui ada tidaknya pengaruh beberapa variabel independen yaitu historis, daya tarik wisata dan electronic word of mouth terhadap variabel dependen yaitu keputusan berkunjung. Persamaan yang diperoleh (Tabel 4):

$$
\mathrm{Y}=0,897+0,388 \mathrm{X}_{1}+0,204 \mathrm{X}_{2}+0,291+\mathrm{e}
$$

Nilai konstanta $=0,897$, artinya variabel historis, daya tarik wisata dan electronic word of mouth secara positif berpengaruh terhadap keputusan berkunjung sebesar 0,897 .

Nilai koefisien regresi variabel historis $=0,388$, artinya ketika variabel historis mengalami peningkatan sebesar satu satuan, sementara variabel tetap, maka variabel keputusan berkunjung naik 0,388.

Nilai koefisien regresi daya tarik wisata $=0,204$, artinya ketika variabel daya tarik wisata mengalami peningkatan sebesar satu satuan, sementara variabel tetap, maka variabel keputusan berkunjung naik 0,204.

Koefisien regresi electronic word of mouth $=$ 0,291 , artinya ketika variabel electronic word of mouth meningkat satu satuan, sementara variabel tetap, maka keputusan berkunjung meningkat 0,291.

Uji F (simultan) digunakan untuk mengetahui apakah semua variabel independen yaitu historis, daya tarik wisata dan electronic word of mouth berpengaruh secara simultan terhadap variabel dependen yaitu keputusan berkunjung. Nilai $\mathrm{F}_{\text {hitung }}=38.158>\mathrm{F}_{\text {tabel }}=$ 2,70 dengan nilai signifikan $0,000<0,05$ artinya Ho ditolak. Hasil analisis uji $\mathrm{F}$ dapat dijelaskan bahwa variabel historis, daya tarik wisata dan electronic word of mouth berpengaruh secara simultan dan signifikan terhadap keputusan Berkunjung di De Tjolomadoe Karanganyar Jawa Tengah.

Uji t (parsial) digunakan untuk mengetahui apakah semua variabel independen yaitu historis, daya tarik wisata dan electronic word of mouth berpengaruh secara parsial terhadap variabel dependen yaitu keputusan berkunjung. Hasil analisis data yaitu:

Nilai $\mathrm{t}_{\text {hitung }} 4,625>\mathrm{t}_{\text {tabel }} 1,985$, signifikannya 0,000 $<0,05$ artinya Ho ditolak, jadi historis secara positif dan signifikan berpengaruh terhadap variabel keputusan berkunjung di De Tjolomadoe Karanganyar Jawa Tengah.

Nilai $t_{\text {hitung }} 2,004>t_{\text {tabel }} 1,985$ dan signifikan memliki nilai $0,048<0,05$ maka Ho ditolak, jadi variabel daya tarik wisata secara positif dan signifikan berpengaruh terhadap variabel keputusan berkunjung di De Tjolomadoe Karanganyar Jawa Tengah.

Nilai $t_{\text {hitung }} 3,345>t_{\text {tabel }} 1,985$ dan signifikannya $0,01<0,05$ artinya Ho ditolak, jadi electronic word of mouth berpengaruh secara positif dan signifikan terhadap keputusan berkunjung di De Tjolomadoe Karanganyar Jawa Tengah.

Hasil $\mathrm{R}^{2}$ menunjukkan bahwa kontribusi variabel historis, daya tarik wisata dan electronic word of mouth terhadap variabel keputusan berkunjung di De Tjolomadoe Karangayar Jawa Tengah 53\%. Tersisa $47 \%$ dipengaruhi variabel lain yang tidak diteliti.

\section{PEMBAHASAN}

Hasil uji F menunjukkan bahwa historis, daya tarik wisata dan electronic word of mouth secara simultan berpengaruh signifikan terhadap keputusan berkunjung di De Tjolomadoe Karangayar Jawa Tengah. Diperoleh $\mathrm{F}_{\text {hitung }}$ sebesar 38.158 , signifikansinya kurang dari 5\% yaitu 0,000 . Hasil tersebut membuktikan bahwa semakin tinggi historis, daya tarik wisata dan electronic word of mouth maka pada keputusan berkunjung di De Tjolomadoe Karanganyar Jawa Tengah akan mengalami peningkatan yang signifikan.

Hasil uji t menunjukkan bahwa historis secara parsial berpengaruh signifikan terhadap keputusan Berkunjung di De Tjolomadoe Karanganyar Jawa Tengah. Diperoleh $t_{\text {hitung }}$ sebesar 4,625, nilai positif koefisien regresi 0,388 sedangkan signifikansinya kurang dari 5\% sebesar 0,000 . Artinya jika pola historis semakin tinggi, maka 
keputusan berkunjung wisatawan di De Tjolomadoe Karangayar Jawa Tengah akan meningkat.

Hasil penelitian ini menjelaskan bahwa sejarah atau historis merupakan semua peristiwa pada masa lampau yang memiliki nilai kehidupan yang luhur dan dapat digunakan sebagai pedoman atau dapat dipelajari pada masa kini dan masa yang akan datang agar jadi lebih baik. Wisata De Tjolomadoe memiliki nilai sejarah, menyadari potensi tersebut pihak De Tjolomadoe berupaya mempertahankan nilai sejarah melalui mesin-mesin pebrik gula pada masa penjajahan Belanda yang dibiarkan tetap berdiri kokoh serta menara yang menjulang tinggi sebagai saksi bisu akan kejayaan pabrik tersebut saat masih beroperasi. Hal ini tentunya membuat wisatawan tertarik untuk berkunjung dan mempelajari sejarah pada tampat tersebut.

Hasil penelitian mendukung penelitian yang sudah dilakukan oleh (Rosikin \& Hartono, 2016), yang berjudul Museum benteng van den bosch (benteng pendem) di kelurahan pelem kecamatan Ngawi kabupaten Ngawi (latar belakang sejarah, nilai, dan potensinya sebagai sumber belajar sejarah). Hasil yang diperoleh dari penelitian tersebut menjelaskan bahwa sejarah memiliki pengaruh terhadap keputusan berkunjung.

Hasil uji t menunjukkan bahwa daya tarik wisata secara parsial berpengaruh signifikan terhadap keputusan Berkunjung di De Tjolomadoe Karanganyar Jawa Tengah. Diperoleh dari nilai $t_{\text {hitung }}$ sebesar 2,004, nilai positif koefisien regresi sebesar 0,204 serta signifikansinya kurang dari $5 \%$ sebesar 0,048 . Artinya jika daya tarik wisata semakin tinggi, maka keputusan berkunjung wisatawan di De Tjolomadoe Karangayar Jawa Tengah akan meningkat.

Penelitian tersebut menyatakan bahwa tempat wisata yang mampu memaksimalkan keunggulan daya tarik wisata yang terdapat pada obyek wisata, memiliki peluang besar untuk mempengaruhi keputusan berkunjung wisatawan. Daya tarik wisata merupakan salah satu faktor yang paling penting yang dievaluasi pengunjung dalam berwisata. Daya tarik wisata juga memiliki peranan penting dalam menggaet wisatawan, daya tarik wisata de tjolomadoe menawarkan keindahan arsitektur bangunan, taman bunga, mesin-mesin peninggalan pabrik gula yang eksotis dan masih banyak lainnya. Hal ini tentunya membuat wisatawan tertarik untuk berkunjung ke tampat tersebut.

Penelitian ini mendukung penelitian yang sudah dilakukakan oleh (Lapian, Mandey, \& Loindong, 2015), yang berjudul Pengaruh advertising dan daya tarik wisata terhadap keputusan wisatawan mengunjungi obyek wisata pantai firdaus di kabupaten Minahasa Utara. Hasil yang diperoleh dari penelitian tersebut membuktikan bahwa daya tarik wisata secara positif dan signifikan berpengaruh terhadap keputusan berkunjung.

Hasil uji t menunjukkan bahwa electronic word of mouth secara parsial berpengaruh signifikan terhadap keputusan Berkunjung di De Tjolomadoe Karanganyar
Jawa Tengah. Hasil diperoleh dari nilai $t_{\text {hitung }}=3,345$, nilai positif koefisien regresi sebesar 0,291 dan signifikansinya kurang dari 5\% sebesar 0,001. Artinya jika pola electronic word of mouth semakin tinggi, maka keputusan berkunjung wisatawan di De Tjolomadoe Karangayar Jawa Tengah akan meningkat.

Hasil penelitian ini menjelaskan bahwa electronic word of mouth merupakan komunikasi secara online, di mana informasi diperoleh melalui testimoni atau review produk, setelah mereka menggunakan suatu produk atau jasa. Hal tersebut dapat berimbas pada keputusan berkunjung wisatawan. Electronic word of mouth sangat efektif digunakan pada penelitian ini mengingat di zaman sekarang setiap individu lebih banyak melakukan aktifitas dengan smartphone nya dan penggunaan internet yang terus meningkat sehingga memenyebabkan konsumen lebih memilih mencari informasi melalui internet dengan melihat informasi produk, review, testimoni dari pengguna terdahulu. Hal ini tentunya memudahkan wisatawan untuk mencari informasi tentang obyek wisata dan membuat wisatawan tertarik berkunjung ke obyek wisata.

Penelitian ini sejalan dengan penelitian (Hapsari et al., 2013) yang berjudul Pengaruh atribut produk wisata dan electronic word of mouth (E-WOM) terhadap keputusan berkunjung pada obyek wisata umbul sidomukti kabupaten Semarang. Hasil yang diperoleh dari penelitian tersebut membuktikan bahwa electronic word of mouth berpengaruh secara positif dan signifikan terhadap keputusan berkunjung.

\section{KESIMPULAN}

Historis, daya tarik wisata dan electronic word of mouth (e-WOM) berpengaruh secara simultan dan signifikan terhadap keputusan berkunjung di De Tjolomadoe Karanganyar Jawa Tengah. Historis daya tarik wisata dan electronic word of mouth (e-WOM) berpengaruh secara positif dan signifikan terhadap keputusan berkunjung di De Tjolomadoe Karanganyar Jawa Tengah secara parsial.

\section{DAFTAR PUSTAKA}

Abdullah, T., \& Tantri, F. 2012. Manajemen Pemasaran. Jakarta: PT. Rajagrafindo Persada.

Bataineh, A. Q. 2015. The Impact of Perceived e-WOM on Purchase Intention: The Mediating Role of Corporate Image. International Journal of Marketing Studies, 7(1), 126-137. https://doi. org/10.5539/ijms.v7n1p126

Fuadillah, I., \& Soebijantoro. 2016. Situs Ngurawan Kecamatan Dolopo Kabupaten Madiun (Latar Sejarah Dan Upaya Pelestariannya). Jurnal Agastya, 6(2), 75-96.

Hamid, A. R., \& Madjid, M. S. 2011. Pengantar Ilmu Sejarah. Yogyakarta: Ombak. 
Hapsari, N. R., Lubis, N., \& Widiartanto. 2013. Pengaruh Atribut Produk Wisata Dan Electronic Word Of Mouth (EWOM) Terhadap Keputusan Berkunjung Pada Obyek Wisata Umbul Sidomukti Kabupaten Semarang. Jurusan Ilmu Administrasi Bisnis Universitas Diponegoro.

Hasan, A. 2010. Marketing Dari Mulut ke Mulut. Yogyakarta: Media Presindo.

Ismayanti. 2009. Pengantar Pariwisata. Jakarta: Grasindo.

Lapian, S. Q., Mandey, S., \& Loindong, S. 2015. Pegaruh advertising dan daya tarik wisata terhadap keputusan wisatawan mengunjungi obyek wisata pantai firdaus di kabupaten minahasa utara. Jurnal EMBA, Vol.3(No.3), page:1079-1088.

Malau, H. 2017. Manajemen Pemasaran. Bandung: Alfabeta.

Mustikasari, A., \& Widaningsih, S. 2016. Pengaruh e-wom terhadap keputusan berkunjung ke tempat wisata di kota bandung. Jurnal manajemen indonesia, vol. 16(2), 95-103.

Ramadhan, F. 2016. Pengaruh kualitas layanan dan

Tabel 1. Hasil Uji Normalitas

\begin{tabular}{lccc}
\hline \multicolumn{3}{c}{ One-Sample Kolmogorov-Smirnov Test } \\
\hline Variabel & $\begin{array}{c}\text { Kolmogorov- } \\
\text { Smirnov Z }\end{array}$ & P-Value & Ket. \\
\hline $\begin{array}{l}\text { Unstandardized } \\
\text { Residual }\end{array}$ & 0,513 & 0,955 & Normal \\
\hline Sumber : Lampiran 5, 2019 &
\end{tabular}

Tabel 2. Hasil Uji Multikolinearitas

\begin{tabular}{lcccc}
\hline \multicolumn{1}{c}{ Variabel } & $\mathrm{B}$ & Tolerance & VIF & Keterangan \\
\hline Historis & 0,388 & 0,606 & 1,650 & $\begin{array}{l}\text { Tidak terjadi } \\
\text { multikolinearitas }\end{array}$ \\
$\begin{array}{l}\text { Daya Tarik } \\
\begin{array}{l}\text { Wisata } \\
\text { Electronic Word } \\
\text { Of Mouth }\end{array}\end{array}$ & 0,204 & 0,553 & 1,807 & $\begin{array}{l}\text { Tidak terjadi } \\
\text { multikolinearitas }\end{array}$ \\
\hline
\end{tabular}

Sumber : Lampiran 5, 2019

Tabel 3. Hasil Uji Heteroskedastisitas

\begin{tabular}{lcc}
\hline \multicolumn{1}{c}{ Variabel } & Sig. & Keterangan \\
\hline Historis & 0,222 & Tidak terjadi heteroskedastisitas \\
Daya Tarik Wisata & 0,821 & Tidak terjadi heteroskedastisitas \\
Electronic Word Of Mouth & 0,518 & Tidak terjadi heteroskedastisitas \\
\hline Sumber : Lampiran 5, 2019 &
\end{tabular}

promosi terhadap keputusan berkunjung ke tempat wisata pantai Samudra Baru. Value Journal of Management and Business, Vol. 1(No. 1), ISSN 2541-397X.

Rosikin, A., \& Hartono, Y. 2016. Museum benteng van den bosch (benteng pendem) di kelurahan pelem kecamatan Ngawi kabupaten Ngawi (latar belakang sejarah, nilai, dan potensinya sebagai sumber belajar sejarah). Jurnal Agastya, Vol. 6(NO. 2), 31-50.

Setiyorini,A., Farida, U., \& Kristiyana, N. 2018. Pengaruh Promosi Melalui Media Sosial, Word Of Mouth Dan Daya Tarik Wisata Terhadap Keputusan Berkunjung Wisatawan Obyek Wisata Gunung Beruk Karang Patihan Balong. Jurnal: Ekonomi, Manajemen Dan Akuntansi, Vol. 2(No. 1 ), Hal.12-17.

Simanjuntak, B. A., Tanjung, F., \& Nasution, R. 2017. Sejarah Pariwisata Menuju Perkembangan Pariwisata Indonesia. Jakarta: Yayasan Pustaka Obor Indonesia.

Smallman, C., \& Moore, K. 2010. Process studies of tourists' decision-making. Annals of Tourism Research, Vol. 37(No. 2), page : 397-422.

Tabel 4. Hasil Analisis Regresi Linier Berganda

\begin{tabular}{lccc}
\hline \multicolumn{1}{c}{ Variabel } & $\begin{array}{c}\text { Koefisien } \\
\text { Regresi (B) }\end{array}$ & t-hitung & Sig. \\
\hline (Constant) & 0,897 & 0,502 & 0,617 \\
Historis & 0,388 & 4,625 & 0,000 \\
Daya Tarik Wisata & 0,204 & 2,004 & 0,048 \\
Electronic word of mouth & 0,291 & 3,345 & 0,001 \\
\hline
\end{tabular}

Sumber : Lampiran 6, 2019

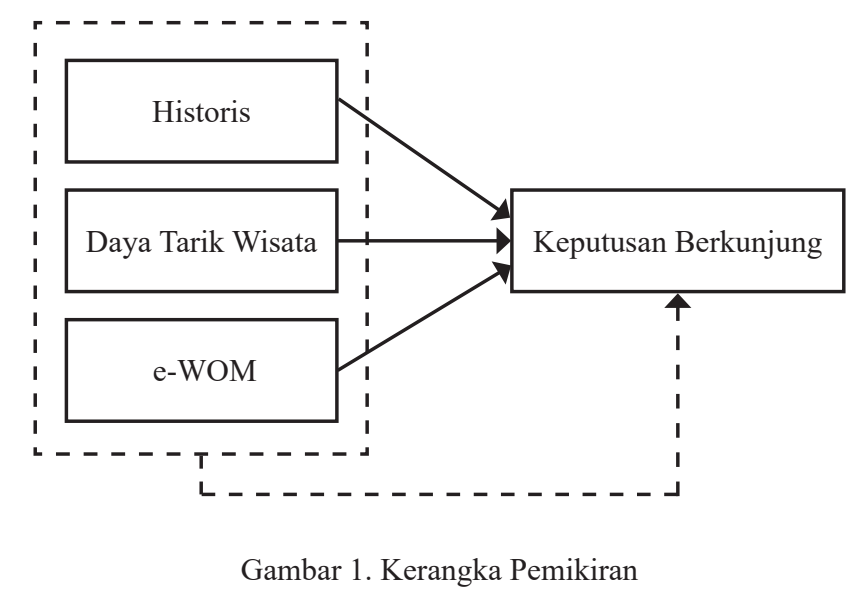

